\title{
Partisipasi Citizen Journalism Terhadap Media Online Untuk Menambah Jumlah Followers Di Akun Instagram Medan Talk
}

\author{
Indah Ajeng Prilicia \\ Universitas Muhammadiyah Sumatera Utara
}

\begin{abstract}
Citizen journalism or to journalists residents in indonesia is relatively new citizen journalism can report a lot of things important quickly before conventional media reported a similar story. A medium that most often used citizen journalism that is social media. Medan talk is one of instagram account who became a container work citizen journalism or contribution of the community that is shaped siber media. This study attempts to mendiskripsikan participation of the community towards instagram account medan talk as one of citizen journalism account in medan. This the kind of research quantitative descriptive uses the method, the size of the population 483 and sample 83 people. The withdrawal of technique sample with simple as using random sampling with using analysis single table. The results of research conducted in variable $x$ by an indicator of how the time it takes to trust the contents of the message to post news medan talk aalah most dominant with the percentage of $30.2 \%$, in variable $y$ with the indicators happy to talk to be a place for learning lessons be journalists residents most dominant 61.4 from $\%$ with the percentage of as much as.
\end{abstract}

Key Word: Citizen journalism, medan talk, participation

\begin{abstract}
Abstrak
Citizen Journalism atau jurnalis warga di Indonesia masih terbilang baru Citizen Journalism dapat melaporkan banyak hal penting dengan cepat sebelum media konvensional melaporkan berita yang sama. Media yang paling sering digunakan Citizen Journalism yaitu media sosial. Medan Talk merupakan salah satu akun instagram yang menjadi sebuah wadah berkarya Citizen Journalism atau kontribusi masyarakat yang berbentuk media siber. Penelitian ini bertujuan untuk mendiskripsikan partisipasi masyarakat terhadap akun instagram Medan Talk sebagai salah satu akun Citizen Journalism di Medan. Jenis penelitian ini kuantitatif yang menggunakan metode deskriptif, jumlah populasi 483 dan sampel 83 orang. Teknik penarikan sampel dengan menggunaka Simple random sampling dengan menggunakan analisis tabel tunggal. hasil penelitian yang dilakukan dalam variabel $\mathrm{X}$ dengan indikator berapa waktu yang dibutuhkan untuk mempercayai isi pesan pada postingan berita Medan Talk aalah paling dominan dengan presentase $30,2 \%$, dalam variabel $\mathrm{Y}$ dengan indikator senang mengirim berita ke Medan Talk dapat menjadi wadah untuk pembelajaran menjadi jurnalis warga yang paling dominan dengan presentase sebesar $61,4 \%$.
\end{abstract}

Kata Kunci : Citizen Journalism, Medan Talk, Partisipasi 
Latar Belakang Masalah

Perkembangan informasi saat

ini bergerak sangat cepat mempengaruhi gaya kehidupan yang

semakin berubah. Hal ini

dikarenakan perkembangan

teknologi informasi serta

komunikasi, manusia sudah mudah

melakukan kegiatan berkomunikasi

sehingga secara tidak langsung

manusia menjadi masyarakat

informasi, dimana saat itu terjadi

peralihan dari masayarakat industri

menuju masyarakat informasi.

Informasi merupakan salah satu

bagian terpenting yang manusia

butuhkan dalam kehidupannya.

Karena manusia adalah mahkluk

sosial yang setiap saat membutuhkan

informasi. Adanya kebutuhan

terhadap informasi membuat

munculnya berbagai media massa,

seperti media cetak dan media

elektronik.
Media massa memiliki peran

penting dalam penyampaian

informasi kepada masyarakat. Peran

media massa sangat menentukan

dalam penyampaian informasi serta

penyebarannya. Media massa

dianggap mempunyai keunggulan

yang dapat mempengaruhi pikiran

manusia sehingga gaya hidup dapat

berubah.

Penemuan baru dibidang

teknologi dan informasi telah

mendorong berkembangnya media

elektronik. Berbagai kemajuan dan

perubahan terjadi percepatan yang

semakin meningkat. Sejak

ditemukannya radio sampai televisi

hitam putih, dibutuhkan waktu yang

cukup lama. Tetapi, pada

perkembangan berikutnya, mulai

dari televisi berwarna sampai

penemuan teknologi komunikasi

interaktif lewat internet,

perubahannya menjadi sangat cepat 
(Muhtadi, 2016 : 70).

Media baru (New Media)

merupakan bentuk dari teknologi

informasi saat ini yang berkembang

pesat menjadi sebuah teknologi yang

membuat manusia hingga

ketergantungan oleh teknologi

tersebut. Kebutuhan manusia akan

teknologi yang semakin canggih

memang tidak bisa dihindari

sehingga media baru menjadi media

informasi seperti media sosial telah

membawa dunia baru dalam

kehidupan manusia.

Internet menjadi media baru

sekaligus perlahan merubah

masyarakat menjadi masyarakat

cyber. Internet hingga saat ini

mampu menduduki peringkat paling

unggul bagi masyarakat, bahkan

internet menjadi sebuah pokok dalam

kehidupan manusia. Perkembangan

di bidang teknologi informasi

merupakan dampak dari semakin kompleksnya kebutuhan manusia akan informasi. Meluasnya jaringan internet menyebabkan internet menjadi salah satu media untuk meningkatkan produktifitas dalam bekerja sebagai sumber pustaka dan mencari informasi yang bersifat global melalui jaringan sosial.

Kehadiran media online pada era globalilasi telah menambah perbendaharaan media baru untu menolong para pembacanya. Teknologi informasi yang telah berhasil merambah dunia baru melalui jejaring sosial bagi para pembaca yang bisa mengonsumsi informasi melalui media cetak, seperti koran atau majalah. Kini dapat dengan mudah memperoleh beragam informasi yang diperlukan melalui internet. Bukan saja informasi tentang peristiwa yang telah terjadi sebelumnya atau bahkan lebih lama lagi, melainkan berbagai 


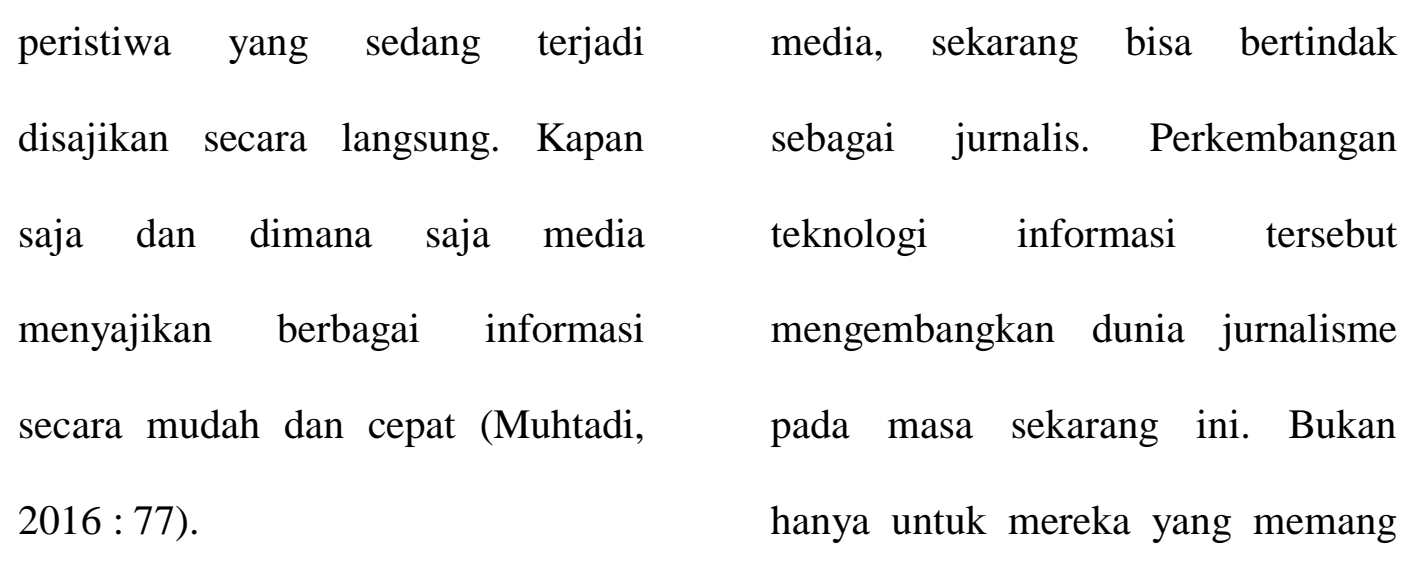

Setiap manusia baik tua pekerjaan sehari-hari sebagai maupun muda rata-rata memiliki jurnalis, namun dunia citizen smartphone yang bisa mereka journalism atau jurnalis warga juga gunakan dalam memenuhi kebutuhan semakin banyak diminati orang dan informasi mereka. Smartphone bisa dikatakan semakin berkembang adalah alat yang paling sering dalam aktivitas jurnalisme ini. Salah digunakan masyarakat dalam satu muncul citizen journalism ini mencari informasi yang mereka ialah ketidakpuasan terhadap media inginkan melalui internet. Karena yang melakukan seleksi isu masyarakat bisa memilih sendiri sedemikian rupa, sehingga gagal informasi apa yang ingin mereka memuaskan publik. Dalam arti dapatkan sesuai dengan keinginan banyak isu yang tidak diseleksi tidak mereka. Salah satu yang digemari mencerminkan kepentingan publik. dan banyak di akses oleh banyak Citzen Journalism adalah orang sekarang ini adalah media keterlibatan warga dalam sosial.

memberitakan sesuatu. Seseorang Warga yang selama ini tanpa memandang latar belakang dipersepsikan sebagai kelompok pendidikan, keahlian dapat 
merencanakan, menggali, mencari, mengolah, melaporkan informasi, tulisan, gambar, foto, tuturan, video kepada orang lain. Jadi setiap orang bisa menjadi wartawan (Nurudin, 2009 : 215).

Sedangkan menurut Nugraha (2012 : 18) menyebutkan bahwa citizen journalism hanyalah masyarakat biasa yang tidak terlatih sebagai seorang wartawan profesional yang memiliki peralatan teknologi sehingga dapat meliput, mencatat, mengumpulkan, menulis, dan menyiarkan di media online atas peristiwa yang terjadi di sekitarnya karena memiliki semangat berbagai dengan pembaca lainnya. Siapapun, kapanpu, dan dimanapun dapat meliput dan melaporkan liputannya melalui media yang ada, baik media konvensional maupun media sosial.

Adapun bentuk-bentuk citizen journalism menurut D. Lasica lewat tulisannya dalam Online Journalism Review, yaitu : Pertama, Partisipasi audiens (seperti komentar-komentar penggunaan yang dilampirkan untuk mengomentari kisah berita, blog pribadi, atau foto yang ditangkap melalui kamera HP, atau berita lokal yang ditulis oleh penghuni sebuah komunitas). Kedua, Berita independen dan informasi yang ditulis dalam website. Ketiga, partisipasi berita situs, berisi komputer-komputer pembaca atas sebuah berita yang disiarkan oleh media tertentu. Keempat, tulisan ringan, seperti dalam milis, dan email. Dan yang terakhir situs pemancar pribadi (video situs pemancar).

New media atau media baru merupakan media yang menggunakan internet, media online berbasis teknologi, berkarakter fleksibel, berpotensi interaktif dan 
berfungsi secara privat maupun publik. Secara umum, media baru tidak hanya menjembatani perbedaan pada beberapa media, namun juga pada perbedaan mengenai batasan kegiatan komunikasi pribadi dengan batasan kegiatan publik. Karakter yang berbentuk digital, memudahkan dalam berkomunikasi dan saling bertukar informasi (Nasrullah : 2011).

Media baru dan media lama sangatlah berbeda, perbedaan tersebut dapat dilihat melalui pendekatan interaksi sosial membedakan media dengan seberapa mirip media tersebut dengan model interaksi tatap muka. Media yang lebih lama memiliki peluang interaksi yang sedikit antara interaksi yang diciptakan seperti halnya radio dan televisi. Media baru lebih memiliki interaksi didalam komunikator dengan komunikannya lebih bebas berkomunikasi dan berinteraksi.

Menurut Antony Mayfield dan iCrossing, media sosial adalah mengenai menjadi manusia biasa. Manusia biasa yang saling membagi ide, bekerjasama dan berkolaborasi untuk menciptakan kreasi, berdebat, menemukan orang yang bisa menjadi teman baik, menemukan pasangan dan membangun sebuah komunitas.

Selain kecepatan informasi yang bisa di akses dalam hitungan detik, menjadi diri sendiri dalam media sosial adalah alasan mengapa media sosial berkembang pesat. Tidak terkecuali, keinginan untuk aktualisasi diri dan kebutuhan menciptakan personal branding. Teknologi-teknologi web baru memudahkan semua orang untuk membuat dan yang terpenting menyebarluaskan konten mereka sendiri. Post di blog, tweet, atau di 
youtube dapat diproduksi dan dilihat

oleh jutaan orang. Pemasangan iklan

tidak harus membayar banyak uang kepada penerbit atau distributor untuk memasang iklannya. Sekarang pemasangan iklan dapat membuat konten sendiri yang menarik dan dilihat banyak orang.

Media sosial sebagai media baru membuat penggunaannya bisa dengan mudah berpartisipasi, berbagi dan menciptakan isi meliputi blog, jejaring sosial, wiki, forum dan dunia virtual. Blog jejaring sosial dan wiki merupakan bentuk media sosial yang paling umum digunakan oleh masyarakat di seluruh dunia.

Instagram merupakan suatu jaringan sosial media yang berbasis photosharing, dengan produk utama yang berbentuk gambar (foto) dan video yang dapat digunakan melalui iphone, ipad, dan android. Berkaitan dengan konteks Citizen Journalism, maka penting untuk diketahui jenis foto jurnalistik semacam apa yang muncul dalam foto-foto di instagram. Hasil penghitungan data menyatakan bahwa secara dominan kategori Spot News menjadi jenis foto jurnalistik yang muncul di dalam objek penelitian. Ciri utama dari kategori Spot News adalah sifatnya tidak terduga, dan diambil dari lokasi kejadian peristiwa.

Akun instagram Medan Talk merupakan salah satu akun yang memanfaatkan sosial media untuk berbagai informasi, khususnya informasi mengenai Medan. Akun tersebut berbagi informasi dengan cara merepost postingan masyarakat Medan yang sudah menge-tag akun @medantalk. Konten yang di informasikan Medan Talk meliputi hiburan, informasi, akademik maupun non akademik, kuliner kota Medan, dan banyak lagi beragam 
informasi yang di unggah instagram

Medan Talk, melalui salah satu

konten yang bernama citizen

journalism.

\section{Metode Penelitian}

Jenis penelitian yang

digunakan adalah jenis metode

penelitian kuantitatif deskriptif yaitu

yang ditunjuk untuk menggambarkan

fenomena-fenomena apa adanya.

Penelitian deskriptif tidak

memberikan perlakuan, manipulasi,

tetapi menggambarkan suatu kondisi

apa adanya. Dalam penelitian

deskriptif ini yang dimaksud adalah

deskriptif kuantitatif karena

gambarnya menggunakan ukuran,

jumlah, atau frekuensi.

Penelitian ini menggunakan

teori uses and gratification yang

lebih menekankan pada pendekatan

manusiawi dalam melihat media

massa. Artinya, manusia mempunyai otonomi, wewenang untuk memperlakukan media. Menurut pendapat teori ini, media mempunyai kebebasan untuk memutuskan bagaimana lewat media mana mereka menggunakan media dan bagaimana media itu akan berdampak pada dirinya (Nurudin, 2007 : 192).

Pendekatan teori uses and gratifications memberikan alternatif untuk memandang pada hubungan antara isi media dan audience, dan pengkategorian isi media menurut fungsinya. Meskipun masih diragukan adanya satu atau beberapa model uses and gratifications, menggambarkan logika yang mendasari pendekatan mengenai uses and gratifications: (1) kondisi sosial psikologis seseorang akan menyebabkan adanya (2) kebutuhan, yang menciptakan (3) harapanharapan terhadap (4) media massa 
atau sumber-sumber lain, yang

membawa kepada (5) perbedaan pola

penggunaan media (atau keterlibatan

dalam aktivitas lainnya) yang

akhirnya akan menghasilkan (6)

pemenuhan kebutuhan dan (7)

konsekuensi lainnya, termasuk yang

tidak diharapkan sebelumnya.

Sebagai tambahan bagi elemen-

elemen dasar tersebut di atas,

pendekatan uses and gratifications

sering memasukkan unsur motif

untuk memuaskan kebutuhan dan

alternatif- alternatif fungsional untuk

memenuhi kebutuhan.

Populasi penelitian ini adalah

mahasiswa Ilmu Komunikasi USU

angkatan 2015, 2016, 2017, dan

2018 yaitu sebanyak 483 orang.

Dalam penelitian ini, menggunakan

simple random sampling, yakni cara

pengambilan sampel dari semua

anggota populasi yang dilakukan

secara acak tanpa memperhatikan strata yang ada didalam anggota populasi itu. Jumlah sample penelitian sebanyak 83 orang.

Penelitian ini menggunakan teknik analisis data kuantitatif. Sedangkan untuk mengetahui hasil dari penelitian yang efektif atau tidaknya menggunakan analisis deskriptif.

$$
\text { Penelitian ini juga }
$$
menggunakan teknik analisis tabel tunggal yang merupakan suatu analisis yang digunakan dengan membaikan varabel penelitian kedalam kategori yang dilakukan atas dasar frekuensi dan presentase. Tabel tunggal merupakan langkah awal dalam menganalisa data yang terdiri dari dua kolom, sejumlah frekuensi dan presentase untuk setiap kategori (Singarimbun, 2006 : 226)..

\section{Hasil Penelitian dan Pembahasan}

Secara umum, partisipasi 
adalah suatu keterlibatan mental dan

emosi serta fisik peserta dalam

memberikan respon terhadap

kegiatan yang melaksanakan dalam

proses belajar serta mendukung

pencapaian tujuan dan bertanggung

jawab atas keterlibatannya.

Partisipasi erat hubungannya dengan

perhatian yang dimiliki, karena

perhatian mengarahkan timbulnya

kehendak seseorang.

Tujuan penelitian ini adalah

untuk mengetahui partisipasi

masyarakat terhadap akun instagram

Medan Talk sebagai salah satu akun

yang berkontribusi mengangkat

berita yang dikirim oleh jurnalis

warga di Medan. Jurnalis warga

dapat menciptakana keberagaman

opini public yang menyoroti kejadian

atau peristiwa yang berada disekitar.

Kegiatan jurnalis warga ini

adalah kegiatan positif yang dapat

menjadikan masyarakat menjadi lebih efektif dalam menyuarakan hal apa saja yang dianggap menarik dan berita tersebut yang bersifat informatif yang dipublikasikan kepada pembaca/ followers.

Kegiatan jurnalis warga ini memang sangat cocok untuk mahasiswa ilmu komunikasi USU yang telah memiliki ilmu dalam dunia komunikasi dan khususnya konsentrasi jurnalistik yang sudah mengetahui kode etik jurnalistik. Dengan menggunakan Teori Uses and Gratification, penelitian ini menekankan kepada pendekatan manusiawi dalam melihat meia massa. Yaitu manusia mempunyai otonomi, wewenang untuk memperlakukan media. Menurut teori ini, media mempunyai kebebasan untuk memutuskan bagaimana lewat media mana mereka menggunakan media dan bagaimana media itu akan 
berdampak pada dirinya. Dari data

yang telah diperoleh dalam

penelitian ini membuktikan bahwa :

Dalam variabel $\mathrm{X}$ dengan indikator berapa lama waktu yang dibutuhkan untuk mempercayai isi pesan pada postingan berita Medan Talk adalah paling dominan dengan presentase $30,2 \%$. Hal tersebut dikarenakan sumber berita yang di posting Medan Talk yang dikirim oleh para jurnalis warga yang bisa terbilang amatir dan belum diketahui apakah para jurnalis warga tersebut benar-benar dapat menyampaikan berita dengan isi pesan yang akurat. Jurnalis warga adalah bentuk partisipasi aktif masyarakat untuk menyuarakan pendapat secara lebih leluasa,terkstruktur, serta dapat diakses secara umum dan sekaligus bisa menjadi rujukan alternatif.

Dalam variabel $\mathrm{Y}$ dengan indikator senang mengirim berita ke
Medan Talk dapat menjadi wadah untuk pembelajaran menjadi jurnalis warga yang paling dominan dengan presentase sebesar $61,4 \%$. Para Citizen Journalism dapat menyuguhkan informasi maupun berita tentang kejadian disekitar masyarakat. Hal yang perlu diperhatikan dalam proses pengolahan berita oleh para jurnalis warga

\section{Penutup}

Dalam variabel $\mathrm{X}$ dengan indikator berapa waktu yang dibutuhkan untuk mempercayai isi pesan pada postingan berita Medan Talk aalah paling dominan dengan presentase $30,2 \%$. Hal tersebut dikarenakan sumber berita yang diposting Medan Talk yang dikirim oleh para jurnalis warga yang bisa terbilang amatir dan belum diketahui apakah para jurnalis warga tersebut 
benar-benar dapat menyampaikan

berita dengan isi pesan yang akurat.

Jurnalis warga adalah bentuk

partisipasi aktif masyarakat untuk menyuarakan pendapat secara lebih

leluasa, terstruktur, serta dapat

diakses secara umum dan sekaligus

bisa menjadi rujukan alternatif.

Dalam variabel $\mathrm{Y}$ dengan indikator senang mengirim berita ke Medan Talk dapat menjadi wadah untuk pembelajaran menjadi jurnalis warga yang paling dominan dengan presentase sebesar $61,4 \%$. Para citizen journalism dapat menyuguhkan informasi maupun berita tentang kejadian disekitar masyarakat. Hal yang perlu diperhatikan dalam proses pengolahan berita oleh para jurnalis warga yaitu harus berisikan nilainilai informatif. Tidak hanya didukung dengan gambar yang bagus tetapi juga harus memiliki nilai yang membuat berita tersebut memiliki kekuatan yang layak untuk diposting.

Dari hasil uji determinasi diperoleh niai $12 \%$. Hal ini menunjukan bahwa partisipasi citizen journalism pada media online akun instagram Medan Talk terhadap alasan untuk menjadi followers Medan Talk sebesar $12 \%$. Sedangkan sisa pengaruh $88 \%$ yang disebabkan karena faktor lain diluar penelitian, penulis hanya menjelaskan sedikit mengenai masalah yang terlihat pada hasil kuesioner saja.

Kemudian, diharapkan Medan Talk menggunakan kosa kata dan bahasa yang lebih tepat sehingga tidak merugikan seorang terutama untuk korban tindakan kriminal dan harus selalu memperhatikan kualitas vide atau foto yang baik untuk diposting agar kedepannya memiliki nilai yang baik bagi para pembaca (followers). 
Lalu, dalam memberikan

informasi harus lebih diperhatikan

serta dapat selalu menerapkan kode

etik jurnalistik sehingga berita yang

dipublikasikan tetap dipercayai

masayarakat.

Serta menjadi wadah untuk

pembelajaran menjadi jurnais warga,

para jurnalis warga harus mengirim

berita yang berisikan nilai-nilai

informative yang membuat berita

memiliki kekuatan yang layak untuk

di publikasikan.

\section{Daftar Pustaka}

Muhtadi, Asep Saeful. 2016. Penghantar Ilmu Jurnalistik. Bandung: Simbiosa Rekatamamedia

Nasrullah, Rulli. 2011. Media Internet: Konstruksi Identitas Keagamaan (Terorisme) di Dunia Cyber. Jakarta: Sincere.

Nugraha, Pepih. 2012. Citizen Journalims: Pandangan, Pemahaman, dan Pengalaman. Jakarta: Kompas Media Nusantara

Nurudin. 2009. Jurnalisme Masa Kini. Jakarta: Rajagrafindo Persada.
Singarimbun, Masri dan Effendy. 2008. Metode Penelitian Survai. Jakarta: Pustaka LP3ES Indonesia. 